\title{
Dust emission from wet, low-emission coke quenching process
}

\author{
Bogusław Komosiński ${ }^{1}$, Bartłomiej Bobik ${ }^{1}$, Tomasz Konieczny ${ }^{1}$, and Ewelina Cieślik $^{1}$ \\ ${ }^{1}$ Polish Academy of Sciences, Institute of Environmental Engineering, M. Skłodowskiej-Curie 34, \\ 41-819 Zabrze, Poland
}

\begin{abstract}
Coke plants, which produce various types of coke (metallurgical, foundry or heating), at temperatures between 600 and $1200^{\circ} \mathrm{C}$, with limited access to oxygen, are major emitters of particulates and gaseous pollutants to air, water and soils. Primarily, the process of wet quenching should be mentioned, as one of the most cumbersome. Atmospheric pollutants include particulates, tar substances, organic pollutants including $\mathrm{B}(\mathrm{a}) \mathrm{P}$ and many others. Pollutants are also formed from the decomposition of water used to quench coke $(\mathrm{CO}$, phenol, $\mathrm{HCN}$, $\mathrm{H}_{2} \mathrm{~S}, \mathrm{NH}_{3}$, cresol) and decomposition of hot coke in the first phase of quenching $\left(\mathrm{CO}, \mathrm{H}_{2} \mathrm{~S}, \mathrm{SO}_{2}\right)$ [1]. The development of the coke oven technology has resulted in the changes made to different types of technological installations, such as the use of baffles in quench towers, the removal of nitrogen oxides by selective $\mathrm{NO}_{\mathrm{x}}$ reduction, and the introduction of fabric filters for particulates removal. The BAT conclusions for coke plants [2] provide a methodology for the measurement of particulate emission from a wet, low-emission technology using Mohrhauer probes. The conclusions define the emission level for wet quenching process as $25 \mathrm{~g} / \mathrm{Mg}_{\text {coke }}$. The conducted research was aimed at verification of the presented method. For two of three quench towers (A and $\mathrm{C}$ ) the requirements included in the BAT conclusions are not met and emissions amount to 87.34 and $61.35 \mathrm{~g} / \mathrm{Mg}_{\text {coke }}$ respectively. The lowest particulates emission was recorded on the quench tower B and amounted to $22.5 \mathrm{~g} / \mathrm{Mg}_{\text {coke }}$, therefore not exceeding the requirements.
\end{abstract}

\section{Legal basis for the measurement of particulate matter and gaseous pollutants emission}

\subsection{Directive 2010/75/EU of the European Parliament and of the Council of 24 November2010 on industrial emissions (integrated pollution prevention and control)}

EU Member States, and therefore Poland, were obliged to transpose the provisions of the Directive by 7 January 2013. As a consequence, Poland has prepared amendments to a

\footnotetext{
${ }^{1}$ Corresponding author: boguslaw.komosinski@ipis.zabrze.pl
} 
number of legislative acts by changing the existing rules on integrated permits, emission standards for installations and land protection. The most important changes were introduced in the Law on Environmental Protection and some other laws. As a result of the legislation introduced in 2011-2013, the existing Community legislation included in the IED [5] has been harmonized and consolidated, replacing six industrial standards [6-11]:

a) Directive 2008/1/EC of the European Parliament and of the Council of 15 January 2008 concerning integrated pollution prevention and control,

b) Directive 2000/76/EC of the European Parliament and of the Council of 4 December 2000 on the incineration of waste,

c) Directive 2001/80/EC of the European Parliament and of the Council of 23 October 2001 on the limitation of emissions of certain pollutants into the air from large combustion plants,

d) Directive 1999/13/EC on the limitation of emissions of volatile organic compounds due to the use of organic solvents in certain activities and installations,

e) Directives 78/176/EWG, 82/186/EWG, 92/112,EWG,

f) Regulation (EC) No 166/2006 of the European Parliament and of the Council of 18 January 2006 concerning the establishment of a European Pollutant Release and Transfer Register.

National legislation imposes:

a) integrated permits,

b) permission for the introduction of dusts and gases,

c) Ordinance of the Minister of the Environment of 4 November 2014 on emission standards for certain types of installations, sources of fuel combustion and devices for incineration or co-incineration of waste.

New directives and regulations aim to improve the prevention and control of pollution caused by industrial activities. They also aim to better the environment as a result of the reduction of industrial emissions and the achievement of the objectives set out in the thematic strategies.

\subsection{Periodic measurements of particulates emission from coke quench towers in the light of the BAT conclusions}

In point 51 of the BAT conclusions for coke oven plants [2], the emission reduction takes place using conventional wet, low-emission quenching technology. The permissible emission, determined as an average during the sampling period, is $25 \mathrm{~g} / \mathrm{Mg}_{\text {coke. }}$. The Mohrhauer method, in accordance with the VDI 2303 standard, is the measurement method.

\section{Coke quench tower}

The final stage of coke production is its wet quenching. After hot coke is pushed from the oven, the quench car travels by rail to a quench tower. The lower part of the quench tower consists of the quench car chamber, and the upper one of the quench chimney. The large steam plume appears from spraying water onto hot coke. The stack effect of the tower and the air suction holes directs the air, water and particles into the atmosphere.

15 to $25 \mathrm{Mg}$ of coke is pushed from the oven(depending on the type), and this amount is subjected to quenching. The water is sprayed onto hot coke from the nozzles, and after quenching the car leaves the tower $[12,13]$.

To remove particulates and tar substances from the steam plume and to unify the stream, baffles are installed inside the quench towers. 


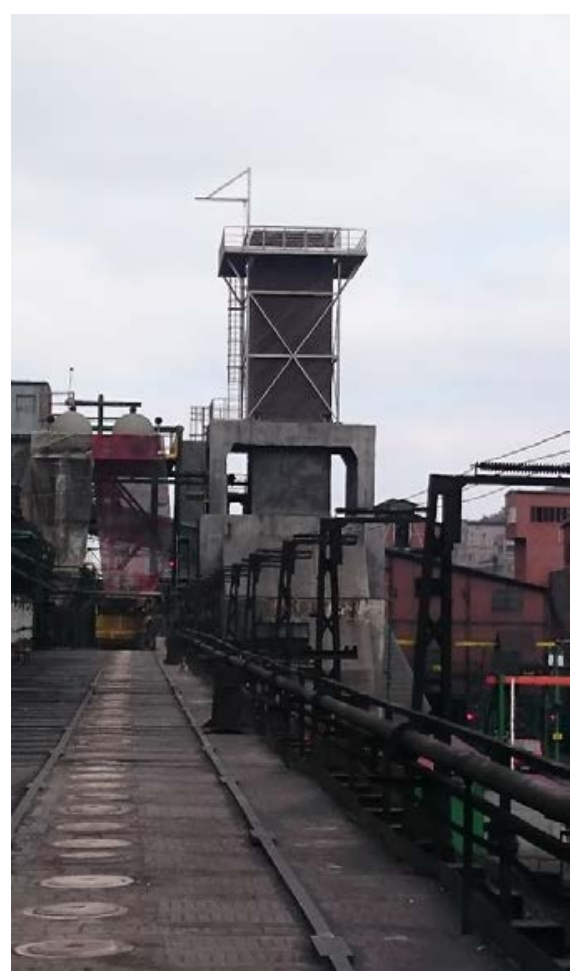

Fig. 1. Coke quench tower.

\subsection{Measurement method}

The methodology for manual determination of particulate emissions from wet quenching using Mohrhauer probes (Mohrhauer's non-isokinetic method), was developed on the basis of German standard VDI 2303 "Limiting of dust emissions in the extinguishing of coke; coking plants and gas works" [3], in accordance with the BAT Conclusions for Coke Oven Plants [2].

Specialized measuring equipment and laboratory facilities are required to determine the concentration of dust discharged into the atmosphere from the quench tower. Materials from which the measuring instruments should be made are the basis for proper measurements.

Non-isokinetic Mohrhauer method is used to measure particulates emission from quench towers, from which the steam plume has the parameters given in Table 1. It is adapted for exhaust gases containing significant amounts of water vapor. This method is dedicated to conventional quench towers with minimized particulates emission.

Table 1. Steam plume parameters.

\begin{tabular}{|c|c|c|}
\hline Parameter & Unit & Range \\
\hline $\mathrm{H}_{2} \mathrm{O}$ & $\mathrm{kg} \mathrm{H} \mathrm{H}_{2} \mathrm{O} \mathrm{kg}_{\text {dry gas }}$ & $0.8-2.0$ \\
\hline Water vapor emission & $\mathrm{Kg} / \mathrm{Mg}_{\text {coke }}$ & $250-500$ \\
\hline Dust emission & $\mathrm{g} / \mathrm{Mg}_{\text {coal }}$ & $20-800$ \\
\hline Flue gas velocity & $\mathrm{m} / \mathrm{s}$ & $0-12$ \\
\hline
\end{tabular}




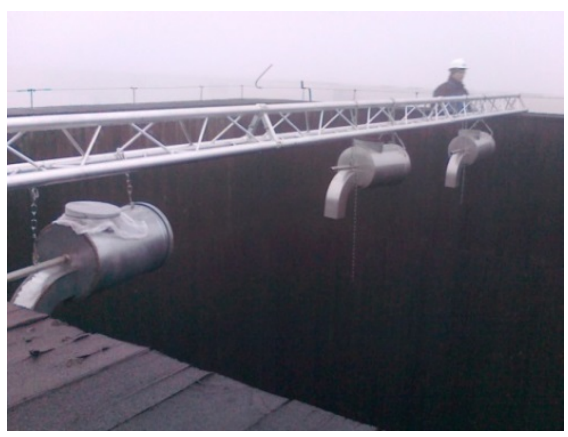

Fig. 2. Top of a quench tower with Mohrhauer's probes installed.

Mohrhauer method consists of capturing a part of the steam plume by the probe. Vapor enters the probe through the square-shaped inlet port. Vapor leaves the probe through the outlet with a fabric (e.g. gauze) with minimal flow resistance. The dust deposited in the probe is transferred quantitatively to the containers after removing the back cover of the probe. The deposition of particulates in the probe is caused by a change of flow direction, centrifugal force, decreasing vapor flow rate, and filter effect of the fabric [14]. Measurements are carried out at the top of a quench tower during the quenching process. In order to achieve satisfactory accuracy, it is recommended to carry out a measurement for 6 - 10 coke quenchings. Total time of measurement may vary as it depends on the production efficiency of a coke plant - usually there are 4-5 quenchings per hour, each lasting for about 5 minutes. Particulates settled on walls of a probe are flushed with water and poured into a condensate container. To determine the amount of dust deposited in the probes, the dust is quantitatively removed from the condensate, dried and weighed using paper filters. Filters are conditioned. The conditioning of filters is carried out at $105^{\circ} \mathrm{C}$ for 2 hours. Subsequently, the filters are cooled in a silica gel desiccator and weighed on a weight with accuracy of $0.001 \mathrm{~g}$. The conditioning and weighing process is repeated until a constant filter mass is obtained.

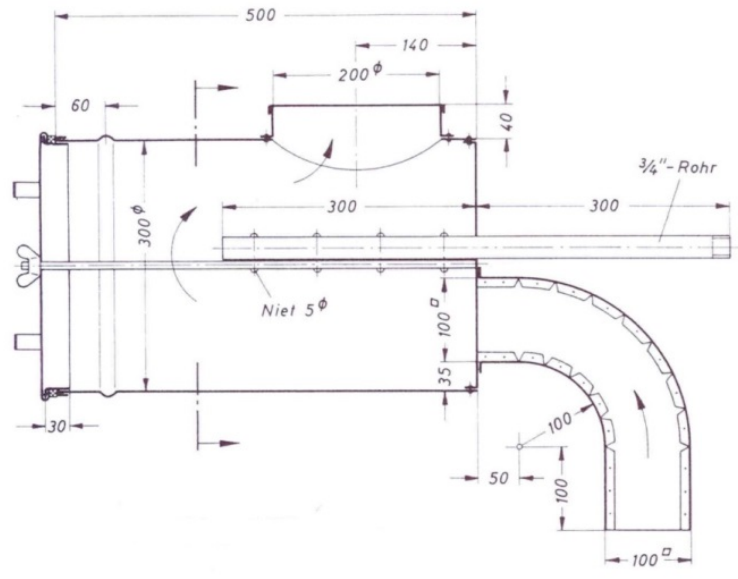

Fig. 3. Mohrhauer's probe [3]. 
Emission is calculated from the following formula:

- $E_{\mathrm{p}}$ - emission, $\mathrm{g} / \mathrm{Mg}_{\text {coke }}$,

$$
E_{\mathrm{p}}=\frac{b \cdot c}{d \cdot e \cdot f}
$$

- $\quad b$ - mass of precipitated dust, $\mathrm{g}$,

- $\quad c$ - area of the quench tower outlet, $\mathrm{m}^{2}$,

$-\quad d$ - area of the probe's inlet, $\mathrm{m}^{2}$,

- $e$ - number of coke quenchings,

- $\quad f$-weight of coke pushed from the oven, Mg.

\section{Results}

Measurements were carried out on three quench towers that were adapted for the use of probes. There were 6 independent measurements of 8 coke quenchings on the two towers and 3 independent measurements of 6 coke quenchings on the third tower.

Tables 2, 3 and 4 show the emission in grams of dust per tonne of quenched coke, as well as the exceedances of the permissible value of $25 \mathrm{~g} / \mathrm{Mg}_{\text {coke }}$ as established by the BAT conclusions. The research carried out indicates that the highest particulates emission was recorded on the quench tower A - $98 \mathrm{~g} / \mathrm{Mg}_{\text {coke }}$, which exceeded the allowable limit by 3.9. Although the tower is one of the most modern, the exceedances may be due to the type of coke produced, distribution of quenching water, or the pollution of water $[14,15]$. Requirements were also exceeded in the case of the quench tower $\mathrm{C}$ - the average emission amounted to $61.35 \mathrm{~g} / \mathrm{Mg}_{\text {coke }}$, exceeding the limit by 2.5 .

The lowest particulates emission was recorded on the quench tower $\mathrm{B}$, whose construction (including the battery) was completed in 2012 . The emission was $22.5 \mathrm{~g} / \mathrm{Mg}$, not exceeding the requirement included in the BAT conclusions. The emission values for the towers A, B and C are shown in Figure 5 and presented in Table 2, 3 and 4.

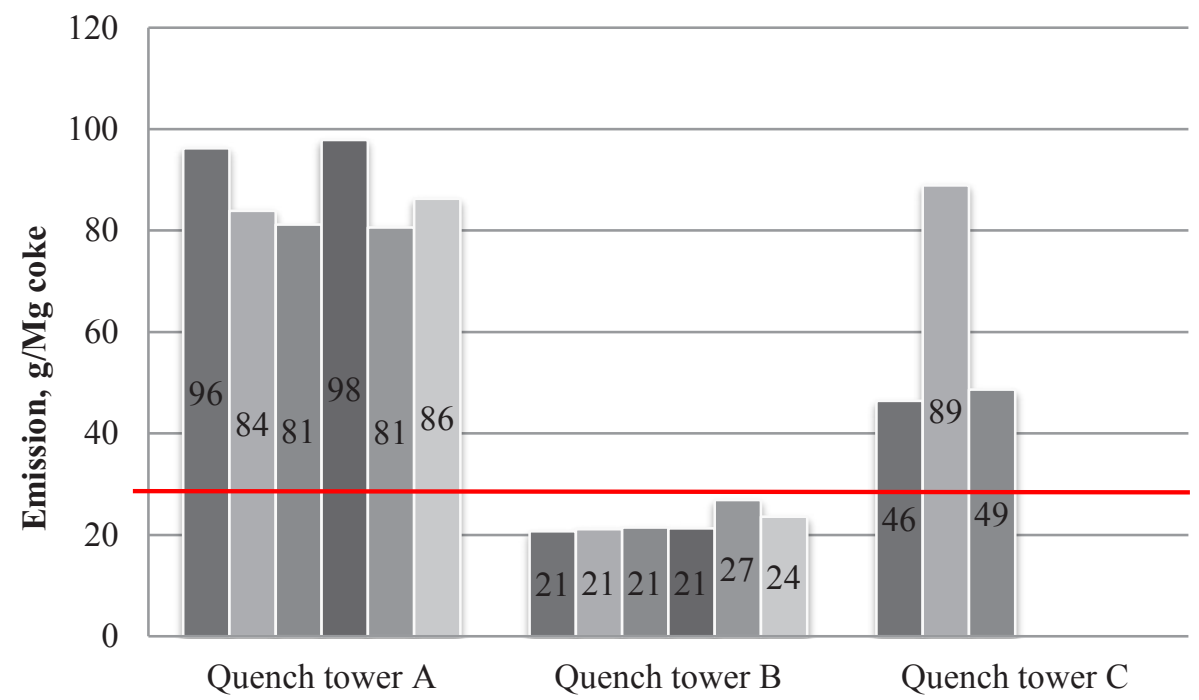

Fig. 4. Particulates emission from the analyzed towers. 
Table 2. Results for the quench tower $A$.

\begin{tabular}{|c|c|c|c|c|c|c|c|c|}
\hline \multicolumn{9}{|c|}{ Quench tower $A$} \\
\hline Number of quenchings & 8 & -- & & & & & & \\
\hline Mass of coke & 196.8 & $\mathrm{Mg}$ & & & & & & \\
\hline Area of the quench tower outlet & 89.1 & $\mathrm{~m}^{2}$ & & & & & & \\
\hline Area of the probe's inlet & 0.06 & $\mathrm{~m}^{2}$ & & & & & & \\
\hline \multicolumn{3}{|l|}{ Measurement number } & 1 & 2 & 3 & 4 & 5 & 6 \\
\hline Emission & \multicolumn{2}{|c|}{$\mathrm{g} / \mathrm{Mg}_{\text {coke }}$} & 95.16 & 83.9 & 81.24 & 97.9 & 80.58 & 85.27 \\
\hline Average emission & \multicolumn{2}{|c|}{$\mathrm{g} / \mathrm{Mg}_{\text {coke }}$} & \multicolumn{6}{|c|}{87.34} \\
\hline \multicolumn{3}{|c|}{$\begin{array}{l}\text { Exceedance of the permissible value of } 25 \\
\qquad \mathrm{~g} / \mathrm{Mg}_{\text {coke }}\end{array}$} & 3.8 & 3.4 & 3.2 & 3.9 & 3.2 & 3.4 \\
\hline
\end{tabular}

Table 3. Results for the quench tower $B$.

\begin{tabular}{|c|c|c|c|c|c|c|c|c|}
\hline \multicolumn{9}{|c|}{ Quench tower $B$} \\
\hline Number of quenchings & 8 & -- & & & & & & \\
\hline Mass of coke & 136 & $\mathrm{Mg}$ & & & & & & \\
\hline Area of the quench tower outlet & 49.82 & $\mathrm{~m}^{2}$ & & & & & & \\
\hline Area of the probe's inlet & 0.06 & $\mathrm{~m}^{2}$ & & & & & & \\
\hline \multicolumn{3}{|c|}{ Measurement number } & 1 & 2 & 3 & 4 & 5 & 6 \\
\hline Emission & \multicolumn{2}{|c|}{$\mathrm{g} / \mathrm{Mg}_{\text {coke }}$} & 20.66 & 21.14 & 21.37 & 21.32 & 26.87 & 23.62 \\
\hline Average emission & \multicolumn{2}{|c|}{$\mathrm{g} / \mathrm{Mg}_{\text {coke }}$} & \multicolumn{6}{|c|}{22.5} \\
\hline \multicolumn{3}{|c|}{$\begin{array}{l}\text { Exceedance of the permissible value of } 25 \\
\mathrm{~g} / \mathrm{Mg}_{\text {coke }}\end{array}$} & 0.8 & 0.8 & 0.9 & 0.9 & 1.1 & 0.89 \\
\hline
\end{tabular}

Table 4. Results for the quench tower $C$.

\begin{tabular}{|c|c|c|c|c|c|}
\hline \multicolumn{6}{|c|}{ Quench tower $C$} \\
\hline Number of quenchings & 6 & -- & & & \\
\hline Mass of coke & 123 & $\mathrm{Mg}$ & & & \\
\hline Area of the quench tower outlet & 89.1 & $\mathrm{~m}^{2}$ & & & \\
\hline Area of the probe's inlet & 0.06 & $\mathrm{~m}^{2}$ & & & \\
\hline \multicolumn{3}{|c|}{ Measurement number } & 1 & 2 & 3 \\
\hline Emission & \multicolumn{2}{|c|}{$\mathrm{g} / \mathrm{Mg}_{\text {coke }}$} & 46.43 & 88.91 & 48.62 \\
\hline Average emission & \multicolumn{2}{|c|}{$\mathrm{g} / \mathrm{Mg}_{\text {coke }}$} & \multicolumn{3}{|c|}{61.35} \\
\hline \multicolumn{3}{|c|}{$\begin{array}{l}\text { Exceedance of the permissible value of } 25 \\
\qquad \mathrm{~g} / \mathrm{Mg}_{\text {coke }}\end{array}$} & 1.9 & 3.6 & 1.9 \\
\hline
\end{tabular}

\section{Conclusions}

During the measurements it was determined that for two of the three quench towers analyzed, the emission limit of $25 \mathrm{~g} / \mathrm{Mg}_{\text {coke }}$ was exceeded. Average emissions for towers $\mathrm{A}$ and $\mathrm{C}$ amounted 87.34 and $61.35 \mathrm{~g} / \mathrm{Mg}_{\text {coke }}$ respectively. Due to the same coke quenching technology and the same measurement method, variations in the results may be due to the type of coke produced, water distribution technology and contamination of water. It was also found that the requirements presented in the BAT conclusions were met only in the case of the quench tower B, which was built in 2012. It should be noted that the need to 
meet the requirements included in the BAT conclusions will force further improvements in coke quenching technology as well as further emission measurements.

\section{References}

1. J. Hehlmann, B. Marcinkiewicz, J. Kapała: Mokre gaszenie koksu w wieżach z wypetnieniem komórkowym, Arch. of Envir. Prot. 25, 33 (1999)

2. 2012/135/EU: Commission Implementing Decision of 28 February 2012 establishing the best available techniques (BAT) conclusions under Directive 2010/75/EU of the European Parliament and of the Council on industrial emissions for iron and steel production (notified under document C(2012) 903)

3. VDI 2303 Limiting of dust emissions in the extinguishing of coke; coking plants and gas works (1966)

4. Polish Standard PN-64/Z-01001 (1964)

5. Directive 2010/75/EU of the European Parliament and of the Council of 24 November 2010 on industrial emissions (integrated pollution prevention and control)

6. Directive 2008/1/EC of the European Parliament and of the Council of 15 January 2008 concerning integrated pollution prevention and control

7. Directive 2000/76/EC of the European Parliament and of the Council of 4 December 2000 on the incineration of waste

8. Directive 2001/80/EC of the European Parliament and of the Council of 23 October 2001 on the limitation of emissions of certain pollutants into the air from large combustion plants

9. Directive 1999/13/EC on the limitation of emissions of volatile organic compounds due to the use of organic solvents in certain activities and installations

10. Directives $78 / 176 /$ EWG

11. Regulation (EC) No 166/2006 of the European Parliament and of the Council of 18 January 2006 concerning the establishment of a European Pollutant Release and Transfer Register

12. K. Klejnowski, Najlepsze dostępne techniki (BAT). Wytyczne dla branży koksowniczej, (Wydawnictwo Instytutu Chemicznej Przeróbki Węgla, Zabrze 2006)

13. M. Tatara, A. Tatara, W. Hummer, B. Komosiński, Proces gaszenia koksu metoda mokra, stan obecny $i$ perspektywy rozwoju $w$ świetle zmian wymogów BAT (Cokemaking Conference 2010, Instytut Chemicznej Przeróbki Węgla, Zakopane 2010)

14. Particulates' emission from wet coke quenching process, Research Procedure PB23, edition 2 from 01.02.2016

15. EPA National Emission Standards for Hazardous Air Pollutants (NESHAP) for Coke Ovens: Pushing, Quenching, and Battery Stacks - Background Information for Proposed Standards. Final Report, (2001)

16. W. L. Filho, I. Butorina Approaches to Handling Environmental Problems in the Mining and Metallurgical Regions, NATO Sci. Ser. 20, 86 (2002) 